\title{
A Research Framework from Low Income Housing Practice in Ibadan, Nigeria
}

\author{
Babatunde Jaiyeoba, Bayo Amole \\ Department of Architecture, \\ Faculty of Environmental Design and Management, \\ Obafemi Awolowo University, lle-lfe, Nigeria \\ tundejaiyeoba@yahoo.co.uk
}

\begin{abstract}
The research firmament is not lacking studies on low income housing. Most studies utilize a top to bottom approach in the sense that the problem identification is from the point of view or the research interests of the researcher. These issues emanate from researchers understanding and perception of a practical problem. A research agenda that focus on issues from the point of view of low income people as revealed in their housing production practice is proposed. This is to ensure that the knowledge contribution of low income research impact on low income housing policy and practice.
\end{abstract}

Keywords: Housing research; low income; building practice; policy

eISSN: 2398-4295 @ 2016. The Authors. Published for AMER ABRA by e-International Publishing House, Ltd., UK.. This is an open access article under the CC BY-NC-ND license (http://creativecommons.org/licenses/by-ncnd/4.0/). Peer-review under responsibility of AMER (Association of Malaysian Environment-Behaviour Researchers), ABRA (Association of Behavioural Researchers on Asians) and cE-Bs (Centre for EnvironmentBehaviour Studies), Faculty of Architecture, Planning \& Surveying, Universiti Teknologi MARA, Malaysia.

https://doi.org/10.21834/ajbes.v1i3.33 


\section{Introduction}

Housing research has not impacted the quantitative problems of housing the poor in the urban areas of the developing world including Nigeria. Public authorities in Nigeria like many countries of the developing world have lost the initiative in the provision of low income housing. There is a high rate of population growth and urbanization and research findings have not influenced policies and practice. Meanwhile, low income people continue the practice of low income housing production. Understanding this practice in different contexts is fundamental to generating research problems and issues to impact housing policies for the poor. One way to enhance understanding through research is to understand the practice. This is to decide the issues that are central to low income housing through the view point of the practitioners in different places. The practice of the research objects is allowed to influence the subjects of the research for findings to be fed back into policies and practice. The aim of this study is to frame a research agenda based on the practice of low income housing in a case study in Ibadan. In order to apprehend the practice, a theoretical perspective that examines low income housing in a non-fragmentary way was utilized. The study is guided by Henri Lefebvre's theory of space to illuminate low income housing production in the social context. The objectives include examining the socioeconomic characteristics and residential histories of the people and the houses built. The resources which the low income people utilized in the process were identified and assessed to arrive at a holistic explanation for housing production in the study area. The holistic approach and the findings from the study generate issues from the spatial practice of low income people useful for framing research problems. The study also proposes the relationship between low income housing practice and research in the process of framing a research agenda.

\section{Literature Review}

Researches in low income housing are from the outsider's point of view or what the anthropologists refer to as the etic perspective. The focus of housing research is markets and politics (Bengtsson, 1995). For the poor, the economic and financial hindrance because of their low income and lack of savings is the focus. The marginalization in income and political exclusion is also researched upon. There are also many studies in mass housing production and alternative or appropriate materials and technology to produce low cost and affordable houses for the poor. Technologies are non- neutral and are an artifact of peculiar materials and ideological interests and reinforce the marginalization of the poor (Johnson, 2011).The findings of these researches and the practical products and processes have little or no effect on housing supply for the low income. Private housing production by all segments of society especially by the low income out paces commercial and public authority provision. This is due to the immense resources possessed by low income people at the individual and communal level (Turner, 1976). Turners approach is closest to studying low income housing from the users' perspective. There are other studies that tend 
to highlight the problems with the product of low income housing. Houses produced in Caracas lack adequate ventilation and their organization resulted in overcrowding. Similar conclusions including structural susceptibility to seismic tremors were drawn in the Mexican case (cited in Walker, 2001). Some writers question the right of governments to dictate what people have to build considering that the willingness and the ability to provide for the poor are lacking (Oliver, 2000). Studies focus on one or two issues in low income housing without focusing on the totality of the process, the houses built and the complete social profile of low income people. Being poor are not a complete explanation of the social profile of low income people (Walker, 2001).

Lefebvre (1991) contends that all aspects of space including low income housing are socially produced. Lefebvre (1991) is filled with concepts relating space with people and constructed environment and all aspects of social space created by people (Mugavin, 1999). Lefebvre opines that production processes and products are inseparable. He has a series of propositions linking social with mental and physical space. Also, there are other triads in his theory of space that are viable tools of analysis. These triads allow for multidimensional analyses of, the multi-dimensional issues involved in low income housing in the social context. This non fragmentary approach allows for a full understanding of low income housing production. This understanding reveals issues and ideas that emanate from low income practice which constitute research problems. They also frame research from the viewpoint of the housing practice of low income people.

The role of the ivory towers and the lines of research being pursued has been a subject of debate since their medieval origin. Questions are being asked about the contribution of universities to economic growth and societal well-being with the continual shrinking of the public sector (Campbell, 2012). At one extreme are thinkers who opine that the academy must continue the search for truth and knowledge even if it is knowledge for knowledge's sake. For this group, the craft of research depends on the ability of the researcher to maintain cognitive and emotional distance from the subject (Kimberly in Walsh et al, 2007). Also, the knowledge produced even though considered useless at first is needed by subsequent academics to produce more useful knowledge. In this sense, knowledge production is a continuum of refining through testing and discarding findings at running cost to society (Grey, 2001). The other extreme assert research is about contemporary issues that can improve the quality of human life (Garland, 2012). This is the only way of not wasting the great ability and education of academics and the time and resources of society to generate findings that have no long term value (Starbuck in Walsh et al, 2007). There is a growing ambivalence among occupants of ivory towers and public authorities on societal impact of academic research in the social sciences. Siemiatycki (2012) opines while citing other writers that the prevailing idea is that research must achieve multiple objectives of scholarly publishing and societal relevance. The societal impact ensures external sourcing of needed funds. Advocates of co-production of knowledge recognize practice knowledge and its integration with theoretical knowledge from research as a cyclical process. Practice 
knowledge embedded in multiple cultures of practice is created and recreated by actors in different contexts. Practice knowledge is also embedded in experience. Research finds systematic and rigorous ways of exploring such experiences to drive inductive and deductive knowledge (McCormack, 2011).

Explorations of housing practice of poor people reveal ideas that refocus research problems to alleviate their housing problem. Lefebvre's theory of space is a comprehensive approach to exploring low income housing production in the social context.

\subsection{Methodology}

The study adopts an approach that is not fragmented as guided by Lefebvre's theory of space. It therefore, examines the low income people with the process adopted and the houses produced in Ogbere, an area with large concentration of low income people on the outskirts of Ibadan. The Ogbere case study allowed for analyses and description from intensive study. Questionnaires were administered as interview schedule on fifty per cent (no= 1003) of the owner occupiers of low income houses in the study area. The first house was randomly chosen, and every other house was then taken. The building owner who was living in the house provided quantitative and qualitative data on personal and family residential history. The owner occupier also provided details of other residents' socioeconomic characteristics. Details of resources utilized and the process of housing production were obtained. Housing characteristics were observed and hidden or nonphysical details obtained from the owner. Other information concerning experience and exposure to building production were requested. Information was obtained on membership of hometown and other indigenous organizations. Quantitative data were subjected to descriptive statistics while qualitative data were subjected to content analyses.

\subsection{Results and Discussion}

The study area is on the outskirts of Ibadan where poor people have been exercising their right to the city for a long time. In spite of their low-income, they were able to negotiate the representational space from the societal abstract space. Many aspects of the representational space are not in conformity with the planners and public authorities' representations of space. Ogbere is a differential space on the suburb transformed from absolute space that involves a contest within everyday life practices. Therefore, the analysis is done within Lefebvre's theory of space to situate it in the social context and multidimensional space. This permit apprehending the multifarious resources low-income people deploy in the spatial practice of housing production. Lefebvre also advocates an analytical shift from houses as products to the totality of the housing process. This analysis therefore, examines the housing production process and the houses built in relation to the people in the social context. This allows for an examination of how human agents with such 
a profile could negotiate Ogbere representational space from the difficult societal abstract space of representations. The low-income exploited the totality of their social profile in the housing production process to achieve houses at different stages of completion in the attempt to conform to societal expectations (Jaiyeoba, 2011).

\subsection{Profile of housing producers}

Ogbere is a product of the experience of people who are married $(80.3 \%)$ or were married but now widowed (14.8\%). Only 1 in 200 owner occupiers are single while $4.1 \%$ are divorcees. Also, the owner occupiers are predominantly between 42 years and 70 years. Those between 56 and 70 years are more than half $(54.7 \%)$ of the housing producers while $28.7 \%$ are between 41 and 55 years. Overall men that are monogamous $(62.8 \%)$ engaged in housing production more than polygamous men (37.2\%). There was an overall average of 5 children per family. Having more than 7 children incapacitated the ability to produce houses.

A quarter of the owner occupiers (24.6\%) had no education at all which means that lack of education is not an insurmountable barrier to housing production. Those that had vocational training after primary and secondary school education were $31.8 \%$ while those with vocational training only were $2.9 \%$ of the owner occupiers. Most of the housing producers in Ogbere were self-employed in the informal sector. Petty traders and petty producers with artisans and technicians and other skilled craftsmen made up $82.2 \%$ while those that worked in the formal sector were $13.5 \%$. Those that worked before in the formal sector and are now retired constituted $5.2 \%$. There is a form of knowledge embedded in vocational training or informal economic activities that made low income housing possible in the study area.

\subsection{Knowledge of building and residential history}

Thirty five percent $(34.5 \%)$ of the housing producers had some knowledge of building. Seventy percent $(70 \%)$ of the $34.5 \%$ acquired the knowledge through informal means by indigenous knowledge. Indigenous knowledge was also passed on from one generation to the other in family houses where $67.2 \%$ earlier lived. One of the housing producers said 'I have an uncle who is a bricklayer he supplied me with useful hints on how to build at my pace'. Also three quarters $(75.4 \%)$ of the housing producers earlier lived in the old or ancient core of the city. Ninety one percent $(90.6 \%)$ of the low income housing producers moved there from elsewhere in the city compared to $50 \%$ in metro manila (Shatkin, 2004). Migrants from other places in Nigeria constitute only $6.8 \%$.

\subsection{Length of stay in the city}

The negotiation of the housing producers for semi legal houses was easier because most were not new entrants into the city. Only 13 of the 926 Ogbere residents had stayed less than 10 years in the city while only 20 had stayed between 11 and 20 years. Those that had 
lived between 21 and 30 years or 31 and 40 years or 41 and 50 years were between 10 and 11 percent each. About twenty percent (19.6\%) of the respondents confirmed they had lived between 61 and 70 years in Ibadan while $8 \%$ had been there for over seventy years.

\subsection{Social capital and resources for housing production}

The indigenous organizations housing producers belonged to; home town association $(8.1 \%)$, skilled workers association (12.9\%), religious association $(24.1 \%)$ and cooperatives $(16.8 \%)$ widened the social network of the low income producers for informal economic activities and social production of housing. Cash gifts from their social network played the most prominent role in housing production for thirty percent (30.2\%) of the producers. Other sources that were not mutually exclusive were children contribution $(29.7 \%)$, credit facility $(29.3 \%)$, savings $(28.4 \%)$ and family contribution $(25.2 \%)$.

\subsection{Choice of neighbourhood and land acquisition}

In the choice of neighborhood affordability was not the topmost consideration. They were not interested in a free land to settle on even when some were entitled to it by inheritance. Ogbere was chosen for being peaceful and quiet. It was considered comfortable with the potential of quickly merging with Ibadan City. The majority did not have the idea of closeness to the place of work or having nearby uses like school for the children and other infrastructure as reasons for choosing the neighbourhood. They exercised their right to a portion of space very near but soon to become part of the city. Most bought land through network of friends. Traditional institutions settled conflicts which rarely occurred. A receipt and a standard agreement obtainable from any nearby typist was the legal document. It is a socio-legal transaction outside the purview of public authorities and professionals.

\subsection{Professional involvement and planning permit}

They employed pseudo professionals for plan drawing and building believing that professionals were inaccessible. At other times, they simply went to the town planning authority in expectation of both the design and approval. Most of the actors in the process were friends of the housing producers. Half of the housing producers $(50.4 \%)$ in the study area had the plan drawn before starting and a quarter (24.6\%) had it drawn along the line as the building was under construction while the remaining quarter $(25.0 \%)$ had no building plan at all. Among those that have building plans two-third $(66.7 \%)$ were sure it was approved by the planning authority. More than twenty percent $(20.5 \%)$ were not sure while $1.3 \%$ knew that it was still in the process, and $11.5 \%$ was sure no planning approval was given to their housing production. The level of compliance with laws and regulations was dictated by what they see in the neighbourhood.

\subsection{Housing production duration, building materials and sweat equity}

The low income housing producers achieved housing production through a gradual or steady approach. The mean time lag between buying land and starting construction was 3 
years with a median of 1 year. In adopting a steady approach, some were able to move into the house between the year they started construction and three years $(61.5 \%)$. In precise terms, the most problematic stages in housing production were land acquisition and roofing because they usually require once and for all expenditure. The roofing stage requires more expenditure for its cultural importance and the associated ceremonial entertainment expenses. It was seen by most of the low income people as the completion of housing production since the house became habitable. For the low income housing producers presenting the house as fully complete by painting is considered a luxury that is done when they are able.

The housing producers in the Ogbere case study did not scavenge for wastes as building materials. Cheap materials not readily acceptable in the urban environment were presented as modern in order to conform to other buildings around and other peoples taste. This explains their masking whatever walling material they used in cement sand plas.

This case study features lower sweat equity. Contributory labor by the housing producer with family and friend is present but low compared to the Latin American self-help builders. The everyday of the Ogbere housing producers is more occupied with economic survival means and sustenance of social relations in space.

\subsection{Building typology and motivation for housing production}

The typical house in the study area is a one-level rooming house $(90.1 \%)$ with rooms on either side of a central corridor. The predominant size of plot for a house is between 450 and 650 square metres. This constituted $61.7 \%$ of the plots in the study area. Most of the boundaries were not firm because only $10.4 \%$ of the land properties were fenced or marked in any other way. The prevalent number of rooms in the rooming house was even with the 6 rooms (41.1\%) and the 8 rooms (38.2\%) being most common (Jaiyeoba, 2013).

The main motivation for housing production is providing accommodation for the family now and in the future for the children. On the aggregate, the housing producers occupied two-thirds of the prevalent rooming houses and three-quarters of the flats. They did not engage in housing production for investment or property rental.

The experiences of the Ogbere case study provide insights into the housing production practice of low income people in the context of a developing country like Nigeria. This practice in turn dictates ideas and issues to be explored by researchers seeking to unravel the housing problem of low income people in similar socio-economic contexts.

\subsection{Research framework from low income housing practice in Ogbere}

It is imperative for a research framework to account for the low income housing production practice in different contexts towards correct policy intervention. It is crucial to employ comprehensive approaches that examine the people in relation to the process and product of low income housing as shown in Fig. 1. 


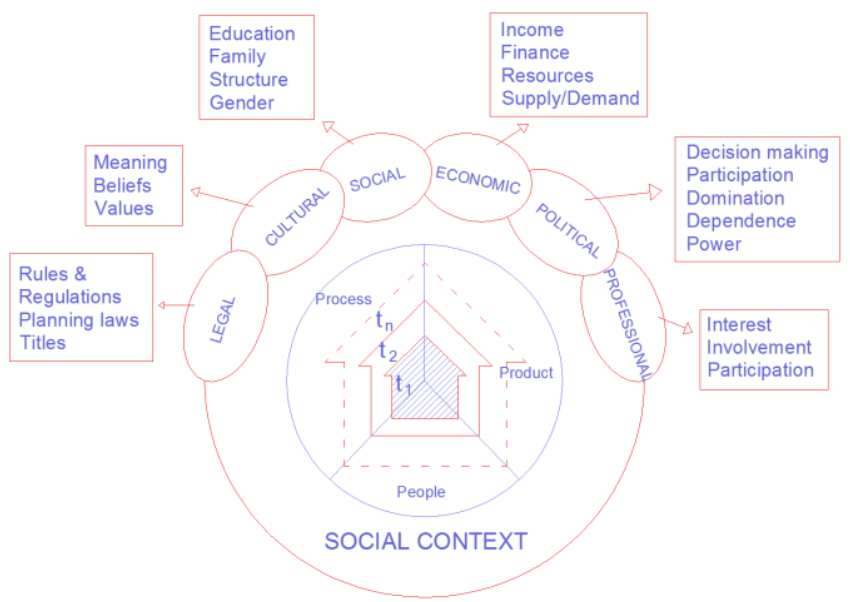

Figure 1: Conceptual Framework for Low Income Housing Study (Source: Jaiyeoba, 2011)

The complete social profile of low income people in different contexts must be studied. In multicultural countries including Nigeria studies is essential for different locations. Case studies allow for in depth description and analysis. Mixed quantitative and qualitative methods are needed. Low income housing literature associates the age and family size with income and savings in the social profile of poor people. Others have been able to include social network and resources possessed by poor people in isolated studies. Issues concerning in depth studies of residential history in addition to length of stay in cities, and factors affecting the choice of housing production location are seldom studied. Even when these are studied their interrelatedness is often ignored.

Finance of land and the actual building process are the focus of most process studies in the literature. The impact of the issues in the social profile such as indigenous knowledge and social capital on economic and human capital cannot be explained by sectional analysis. How poor people constructively engage professionals and non-professionals and public authorities to legalize housing production vary in different contexts. Many studies assume that low income housing constitute slums and are therefore, necessarily illegal. It is also assumed that sweat equity is high in low income housing production. In practice, the entire housing production process is to be treated as part of the everyday of poor people. All issues in the everyday of low income people must be part of a research framework emanating from practice.

The standard of houses produced, and the quality of the neighborhood is common in the literature. The impact of these on life outcomes and the overall environment is also well documented. Research is yet to understand the perception and aspirations of low income 
people about many issues including what spaces are critical and when is a house complete. Why low income people build what they build in different contexts is not fully understood. The relationship of the houses built to the complete social profile and different resources that underlie successful housing production can only be explained from practice. The motivation for housing production and its determinants as against other recommended options like renting for low income people is an important problem for research that emanate from practice.

Research framework must also account for the context in which the people negotiate the process and product. This includes the socio-economic and political milieu. Also, the technological and cultural characteristics of the context are important. The administrative and legal constraints to housing production are critical to explanations of housing production by the poor. Low income housing production practice is a reflection of the balance between institutional standards and practical standards. The cultural practices involved in the housing production process may aid and or abet the housing production process in different ways. A research framework must take on all these issues simultaneously in different contexts.

\subsection{Conclusion}

The study has demonstrated the issues that need to be studied to apprehend low income housing practice through the case study in Ibadan. It has also shown that a comprehensive approach like Lefebvre's theory of space allows for explanation of low income housing production in different social contexts. Low income housing production is multi-dimensional and contextual, and research in different contexts is essential. A research framework that focuses on issues from the point of view of low income people as revealed in their housing production practice is proposed. This is to ensure that the knowledge contribution of low income research impact on low income housing policy and practice.

\section{Acknowledgement}

Study was personally funded.

\section{References}

Bengtsson, B. (1995). Politics and housing markets for normative arguments. Scandinavian Housing and Planning Research, 12.

Campbell, H. (2012). Planning to change the world: Between knowledge and action lies synthesis. Journal of Planning Education and Research, 32, 135. 
Jaiyeoba, B., \& Amole, B. / Asian Journal of Behavioural Studies, AjBeS, 1(3) September/October 2016 (p.1-11)

Garland, R. (2012). The humanities: Plain and simple. Arts and humanities in Higher Education, 11, 30.

Grey, C. (2001). Re-imaging relevance: A response to Starkey and Madan. British Journal of Management, 12, S27-S32.

Jaiyeoba, B. (2013). The quality of housing produced by the low income in a developing country: A case study in Ibadan, Nigeria. Asian Journal of Environment-Behaviour Studies, 4(11).

Jaiyeoba, B. (2011). Social production of private low income housing in Ogbere, Ibadan. Saarbrucken: LAP LAMBERT Academic Publishing.

Johnson, C. G. (2011). The urban precariat, neoliberalisation and the soft power of humanitarian design. Journal of Developing Societies, 27, 445.

Lefebvre, H. (1991). The production of space. Oxford: Blackwell.

McCormack, B. (2011). Engaged scholarship and research impact: Integrating the doing and using of research in practice. Journal of Research in Nursing, 16(2), 111-127.

Mugavin, D. (1999). A philosophical base for urban morphology. Urban Morphology, 3(2), 95-99.

Oliver, P. (2000). Ethics and vernacular architecture, in Warwick Fox (ed.), Ethics and the built environment. London \& New York: Routledge.

Shatkin, G. (2004). Planning to forget: Informal settlements as 'Forgotten places' in Metro Manila. Urban Studies, 41, 2469- 2484.

Siemiatycki, M. (2012). The role of the planning scholar: Research, conflict and social change. Journal of Planning Education and Research, 32, 147.

Turner, F. C. J. (1976). Housing by people: Towards autonomy in building environments. London: Marion Boyars.

Walker, A. (2001). The social context of built form: The case of informal housing production in Mexico City. Working paper No 114. Development and Planning Unit, University College, London.

Walsh, J. P., Tushman, M. L., Kimberly, J. R., Starbuck, B. \& Ashford, S. (2007). On the relationship between research and practice: Debate and reflections. Journal of Management Inquiry, 16(2), 128-154.

Seamon, D. (1982). The Phenomenological Contribution to Environmental Psychology, Journal of Environmental Psychology, 2, 119-140.

Shah, R.C. and Kesan, J.P. (2007). 'How Architecture Regulates'. Journal of Architectural and Planning Research, 24 (4), 350-359.

Sri Nammuni, V. (1991a). Teaching of Architectural Design: A Moratuwa Experiment part 1 in The Sri Lanka Architect. 100 (7).

Sri Nammuni, V. (1991b). Christopher Jones and Design Methodology. Teaching of Architectural Design: A Moratuwa Experiment part 2, in The Sri Lanka Architect, 100 (8). 
Jaiyeoba, B., \& Amole, B. / Asian Journal of Behavioural Studies, AjBeS, 1(3) September/October 2016 (pp.1-11)

Sri Nammuni, V. (1991c). From Learning to Teaching Architecture. Teaching of Architectural Design: A Moratuwa Experiment part 3, in The Sri Lanka Architect, 100 (9).

Sri Nammuni, V. (1991d). Design Teaching at Moratuwa. Teaching of Architectural Design: A Moratuwa Experiment part 4, in The Sri Lanka Architect,100 (10).

Shultz, C. (1971). Existence, Space and Architecture. Praeger Publishers, London. 